\title{
An Experimental Study of a Software Based Teaching Methodology in an Undergraduate Negotiation Course
}

\author{
Mohammad Ayub Khan ${ }^{1} \&$ Giovanni Maria Baldini ${ }^{2}$ \\ ${ }^{1}$ School of Business, University of Monterrey, Monterrey, Mexico \\ ${ }^{2}$ School of Business, Tecnologico de Monterrey, Monterrey, Mexico \\ Correspondence: Mohammad Ayub Khan, School of Business, University of Monterrey, Monterrey, Mexico. \\ E-mail: Mohammad.khan@udem.edu
}

Received: June 22, 2020 Accepted: July 28, 2020 Online Published: August 17, 2020

doi:10.5539/jel.v9n5p75 URL: https://doi.org/10.5539/jel.v9n5p75

\begin{abstract}
Cross-cultural negotiation courses have been taught for many years both at graduate and undergraduate levels, using conventional pedagogical approaches such as classroom-based lectures, material readings, and paper-pencil based negotiation exercises. In the contemporary world of higher education, it is often expressed by the faculty that students show lack of enthusiasm, interest, and motivation to actively participate in such learning activities. Moreover, semesters after semesters faculty find students becoming less and less engaged in conventional learning activities. In this learning atmosphere, as teachers, we find it really challenging to create and maintain a minimum level of the required interest in students and motivate them to pay attention, ask questions, and participate actively in classroom sessions. Therefore, in this study we propose to the faculty who are teaching negotiation related courses to use software-based teaching strategy in order to engage students in a more enjoyable manner and provide them with an interactive learning environment.
\end{abstract}

Keywords: negotiation, negotiation strategies, negotiation software, software-based learning

\section{Introduction}

Today's students are technology-native and savvy. They like and prefer to work with technology related products and services. They are more efficient in performing technology-based activities and tasks. The existing research works on contemporary pedagogical approaches and their effectiveness, find that the vast majority of the researchers are strong supporters of the idea of integrating educational technologies, with the exiting pedagogical approaches. With the advent of information and communication technologies (ICT), the millennial students are found to be fond of ICT related and ICT based activities. These students use ICT for almost every activity they need to carry out whether it is inter-personal communication, doing school assignments or conducting routine social affairs. In recent times, a majority of the university professors complain about the following issues associated with students:

- Lack of interest in and commitment for learning.

- Difficulty in effectively engaging students with learning.

- Developing across-discipline competencies such as self-managed learning and collaboration.

- Developing disciplinary competencies in students (in this case, negotiation skills).

We find that in the existing theories and practices, the application of software - may they be operational or learning - has grown tremendously in popularity, and its usage in the education field has become an important preoccupation for more and more universities all over the world (Meher, 2015). As the day by day changes in the technology, technical requirements and techniques of the industry change simultaneously (Meher, 2015). Therefore, researchers in the field of higher education are of the view that the use of software in teaching can and will provide a better support, more clear and visual learning activities in classroom for students and thus, helping students understand better the concepts and theories (Meher, 2015). Studies (OECD, 2010) also find that using any software for teaching purposes will save the time of faculty and students and promote collaborative learning. Collaborative learning is an important learning strategy for educators to use in their classrooms to ameliorate student knowledge by combining strengths, sharing responsibilities and learning from one another (Roblyer, 
2006).

In summary, given the prevailing teaching and learning context, we advocate and promote the use of software to teach a negotiation course and other related subjects since it will enhance the interest and motivation levels of students. While advocating a software-based teaching methodology, we also want to explore replies to these general research questions:

- Is the use of technology like software in teaching effective in motivating students to be engaged in learning?

- Does the application of educational technologies as a pedagogical support system make differences in developing competencies in students when compared to the conventional pedagogical approaches?

- Which are the potential pros and cons of using educational technologies such as a software, as a pedagogical support system?

\section{A Theoretical Framework}

The rapid growth of ICT has brought remarkable changes in the twenty-first century, as well as affected the demands of modern societies (Buabeng-Andoh, 2012). ICT is becoming increasingly important in our daily lives and in our educational system. Therefore, there is a growing pressure on the educational institutions to use ICT to teach the skills and knowledge students need for the 21 st century. Realizing the effects of ICT on the workplace and everyday life, today's educational institutions try to restructure their educational curricula and classroom facilities, in order to bridge the existing technology gap in teaching and learning. It is critically important to pay due attention to the usefulness of the technology when discussing instruction, education, or training issues. The use of computers for teaching and learning purposes is opening a new area of knowledge and offer a tool that has the potential to change some of the existing educational methods. As the computer use continues to increase manifolds in our social and professional life, faculty must also prepare themselves to be able to use computers and computer related facilities and supports within their classrooms (McCannon \& Crews, 2000; Snelbecker, 1999). In summary, in order to create a conducive environment for technology-learning integration, it is vital that the educational institutions must promote (Tondeur, van Keer, van Braak, \& Valcke, 2008):

- Collaborative learning.

- The use of computer related technologies for creating and conduction learning activities.

- Habits in students to conduct research using computers and computer related technologies

- The potential benefits of information and computer literacy among students and faculty.

\subsection{Learning Technology}

The learning technology is defined as solutions to instructional problems involving social as well as machine technologies in order to improve the effectiveness and efficiency of learning in the context of education (Gentry, 1995). The learning technology is also considered as means of media with four different focuses: media for enquiry (i.e., data modelling, spreadsheets, hypertext, etc.); media for communication (i.e., e-mail, graphics software and simulations); media for construction (i.e., robotics, CAD, control systems), and media for expression such as interactive video, animation software, music composition (Bruce \& Levin, 1997).

\subsection{Information and Communication Technology (ICT) Based Learning}

Themes like mobile learning, electronic learning, flexible learning, online learning and virtual learning are hot topics in the academic world these days. Moreover, the importance of ICT in the evolution and revolution of the modern education system is an undisputable phenomenon. Over the past several years the emergence and the use of educational technologies have been on the rise (Downing \& Garmon, 2001). This trend has forced universities to increase substantially their investments in educational technologies, technology experts and faculty training as never before. In parallel to the changes brought about by new technologies in the field of education, researchers have become equally concerns about the actual and potential benefits of integrating such technological supports (i.e., the use of software) into the existing pedagogical frameworks. Faculty may use other computer-based technologies as well such as electronic mail, Web pages, chat rooms, and electronic bulletin boards in classrooms to facilitate communication with the students (Driver, 2002). Social networks such as Facebook, Twitter and LinkedIn are also popular among the young generation to share information and communicate interactively. 


\subsection{For and Against ICT Based Learning}

While comparing the pros and cons of the uses of technology for teaching and learning purposes it becomes a crystal-clear fact that the benefits of using technology for learning purposes can outnumber the potential costs affiliated with it. For example, technology helps students' access, gather, analyze, present, transmit and simulate information at any place, at any-time and through multiple means (See, 1994). Technology has brought revolutionary changes in the education industry and therefore, "the impact of technology is one of the most critical issues in the contemporary education system" (Webber, 2003).

\subsection{Software Based Pedagogical Approach}

In the field of negotiation, practices and models such as virtual negotiation, computer-mediated negotiation, and online negotiation have substituted the conventional or face-to-face negotiation practices whereby creating challenges and opportunities for the business managers, sales people and business negotiators. Therefore, our students before graduating should be:

- Introduced to the technological advances which are relevant to their field-specifics.

- Helped learn how to use such technologies to support managerial decision making.

- Taught the application and benefits of the existing technologies in their corresponding disciplines.

Furthermore, the use of software for teaching and learning purposes can assist students in a tangible fashion to be: organized; process-oriented; time-oriented; and to be self-learners while keeping them engaged with the learning activities.

\section{The Research Approach}

In order to study the benefits of a software-based teaching strategy, a negotiation software namely "iDecisionGames" was incorporated into the course of cross culture negotiation and communication, during the semester of August-December 2018. This software is used to train corporate managers in business negotiation and as well as to teach negotiation courses in a more practical manner. The software covers different variables with regard to strategic negotiations and allows students apply their theoretical understandings of the negotiation subject by practicing planning, implementing and evaluating both the process and outcomes involved in any negotiation episode. In this particular experimental course, students were provided with the basic theoretical information on the negotiation subject prior to ask them to work with the software to negotiate using a variety of business and management contracts.

In order to perform this classroom-based experiment, the following steps were undertaken:

- Two sections of the negotiation course were selected for this exercise. Both sections having their own class hours and classrooms.

- One of the sections with 30 students was provided with the negotiation software in addition to teaching and learning materials and exercises. We called this section, the research section/group. The other section with 35 students, was provided with the teaching and learning materials including regular case studies, but not the negotiation software. We named this section, the regular section/group.

- Students placement in either of these two sections were students' own decisions.

- Pretest questionnaire covering students' profile, current knowledge of negotiation, and self-confidence level in negotiation, was applied to students in their respective sections in the beginning of the semester.

- In the beginning of the semester, students of both sections were provided with all the required orientation/information concerning the importance and application of the negotiation.

- The research section was provided additional explanations on the application and importance of the negotiation software (iDecisionGames).

- All other variables (controllable and non-controllable) such as the course evaluation system, feedback system, advisory time, instruction materials, and profile of students were the same in both sections. Likewise, these sections were similar - in relative terms - to each other in forms of:

a. Number of national and international students.

b. Female and male students.

c. Students of similar ages and experiences.

The purpose of dividing the sections into two, and using software in one class, and keep the other section 
traditional, was to evaluate the effectiveness of the software-based negotiation course in:

- Improving student's confidence level in negotiation.

- Achieving better grades on the course.

- Having positive learning experience.

We find that such a study design can overcome the weaknesses identified in past evaluations of teaching methods that have relied solely on end-of-course reaction surveys, instructor impressions, or anecdotal evidence (Shaw, Fisher, \& Southey, 1999). The outcomes of this study will help us in understanding the potential benefits of using educational technologies (negotiation software in this case) and to make the teaching job easier and time-effective for the faculty, and similarly making the learning environment more interesting, dynamic and effective for the students.

\subsection{Sampling}

This was small-scale experimental study based on two different sections of the same negotiation course. Of the participating students in this study:

- Around $80 \%$ were Mexicans and business students.

- Around $10 \%$ were international program students hailing from different countries and on exchange programs at Tecnologico de Monterrey and with different academic backgrounds.

- Another close to $10 \%$ students were Mexican non-business students undertaking the course as an optional course.

- These were undergraduate and 5th semester above students.

\subsection{Data Collection}

Four broader data collection mechanisms were used to study the benefits of the software-based teaching methodology to teach an undergraduate negotiation course.

\subsubsection{Students' Evaluation of the Faculty Performance}

As in any other classes or sections, at the end of each and every semester, students are given the option by the university management to evaluate the overall teaching performance of their respective professors. Although, eight (8) variables are used by students to do this evaluation, however, two of them are considered as the core ones by the academic leadership to measure the global performance of a faculty. Those two variables and measurement scales are:

a. I (will) recommend the professor to my other colleagues, in a scale of " 1 to 10 " where " 1 " stands for total disagreement with the statement, and " 10 " stands for the total agreement with the statement.

b. One of the best professors so far in my academic/study program at the university, in a scale of " 0 to 1 " where "0" means, No and " 1 " means "Yes".

Additionally, students' comments were also added to the information analysis concerning the faculty performance in both sections under study.

\subsubsection{Class Observation Report}

One mechanism used to gather information was the class observation notes. During the 15 weeks long sessions, we observed the performance and behavior of the students in both sections. In order to enrich the research outcomes, our observation notes included information about these particular variables:

- Students behavior (cooperative-disturbing).

- Stress level of the students (high-low).

- Level of engagement with the class activity (high-low).

- Attitudes of the students (positive-negative)

- Time management (Good use of class time vs waste of class time).

\subsubsection{Comparing the Grades of Students}

Comparing the course grades (grade achievements of both groups). The grading scale used ranges from "0 to 100 ", where "100 points" being the highest grades and "0" being the lowest grades, in any course. The passing grade for students is "70 points". 


\subsubsection{Pre-Post Course Questionnaires}

Two similar questionnaires were developed in order to collect data from the students. The questionnaires consisted four sections:

- Respondents profile: This included gender, semester level, nationality and academic background of the students.

- Past experience: This included any past work experience and knowledge of professional work environment.

- Knowledge of negotiation: This included the previous knowledge of the negotiation subject (theories and concepts).

- Negotiation self-confidence assessment: In a scale of " 1 to 5" (where 1 is strong disagreement and 5 is strong agreement, with the statement), students were asked to rate15-statements indicating the level of knowledge of the negotiation discipline.

\section{Information Analysis and Outcomes}

In total, 30 students participated in the research section and 35 students participated in the regular group. As shown in Table 1, below that students who appropriately responded the questionnaire in the regular group were $31 / 35$, and in the research, group were 26/30. The response and accuracy rate remained quite high.

Because of the small number and homogeneity of the study participants, we did not study the relationship (direct or indirect or causal) of the student's profile in mediating or moderating the relationship between the self-confidence assessment score and the software-based teaching methodology. Especially, in variables such as gender, work experience, academic performance and semester level, respondents had similarities than differences. In fact, statistics will not prove something otherwise which could be significant enough to disapprove this theoretical assumption.

Table 1. Regular group and research group students profile

\begin{tabular}{lllllllllll}
\hline Section & Gender & \multicolumn{3}{c}{ Nationality } & \multicolumn{2}{c}{ Work Experience } & \multicolumn{2}{c}{ Academic Grades } & \multicolumn{2}{c}{ Semesters Level } \\
\cline { 2 - 24 } & Male & Female & Mexican & International & Yes & No & Above 85 & Below 85 & Above 5th & Below 5th \\
\hline Regular & 10 & 21 & 25 & 6 & 23 & 8 & 18 & 13 & $90 \%$ & $10 \%$ \\
Research & 11 & 15 & 15 & 11 & 20 & 6 & 18 & 8 & $90 \%$ & $10 \%$ \\
\hline
\end{tabular}

\subsection{Students Evaluation of the Faculty Performance}

As described earlier that two of the 8 faculty evaluation variables were used to analyze the impacts of the software-based teaching strategy on the faculty performance. Table 2, demonstrates that students in the regular section (section No 1) assigned higher points (9.44) to the faculty when it comes to the variable of "I recommend the faculty to my other colleagues". Similarly, faculty performance remained superior $(0.69)$ in the regular section (section 1) than in the research section (section No. 3).

Table 2. Students evaluation of the faculty performance

\begin{tabular}{lllllll}
\hline Course & $\begin{array}{l}\text { Section } \\
\text { No. }\end{array}$ & $\begin{array}{l}\text { Total } \\
\text { Students }\end{array}$ & $\begin{array}{l}\text { Students } \\
\text { Evaluating }\end{array}$ & $\begin{array}{l}\text { Participation } \\
(\%)\end{array}$ & $\begin{array}{l}\text { Recommend the } \\
\text { Professor (Average) }\end{array}$ & $\begin{array}{l}\text { Career Best Professor } \\
\text { (Average) }\end{array}$ \\
\hline $\begin{array}{l}\text { Negotiation and Intercultural } \\
\text { Communication }\end{array}$ & 1 & 34 & 32 & 94.12 & 9.44 & 0.69 \\
$\begin{array}{l}\text { Negotiation and Intercultural } \\
\text { Communication }\end{array}$ & 3 & 30 & 22 & 73.33 & 9.05 & 0.59 \\
\hline
\end{tabular}

Some of the frequently expressed comments from students regarding the use of software in a negotiation course were:

- Technicalities involved in working with the software.

- Inadequate training to run the software.

- Time consumption in operating the software.

- Ups and downs in Internet speed and availability (software was Internet based). 
- Negotiation process and modalities were too structured leaving small space for deliberation.

- Adding software means adding more difficulties and cost to the course.

After reading these comments of the students, we believe that students in the research section were not feeling comfortable with the use of software. Therefore, students may have decided to assign low performance score to the faculty in the research section.

\subsection{Class Observation Report}

During the semester we kept observations reports of all classes of both sections. Generally, students in the research section were looking stressful but at the same time excited to experience a software and inquisitive about the benefits of working with the software. Whereas in the regular section, students were more relaxed and calmer expecting and encountering a familiar classroom environment. Nonetheless, students in regular section looked less interested in the course activities (negotiation exercises) but less stressful. Table 3, highlights few of the observed variables during the semester.

Table 3. Class observation report

\begin{tabular}{lll}
\hline Variables & Traditional Section & Software based Section \\
\hline Students behavior (cooperative-disturbing) & Less cooperative & Cooperative \\
Stress level of the students (high-low) & Less stressful & More stressful \\
Level of engagement with the class (high-low) & Low level of engagement & High level of engagement \\
Attitudes of the students (positive-negative) & Neutral & Negative \\
Time management (Good use of class-waste of class time) & Less effective time management & Good use of time \\
\hline
\end{tabular}

Overall, although there were some negative reactions from the students of research section, however, positive points observed outweigh those negatives, with regard to the use of a software for teaching purposes:

- Keeping students engaged.

- Keeping students busy and concentrated on the task in hand.

- Having less bored students and class.

- Allowing students to work with technology.

- Better management of the class time.

- New generation of students prefer to work with technology to do their personal stuff as well as their school chores.

- Modern era learners tend to be multi task, short-cut oriented, and highly dependent on technology to solve problems.

\subsection{Comparing the Grades of Students}

As an indicator of the effect of a particular pedagogical approach applied in a classroom, students' end class grades in both sections were also included in our analysis. Table 4, shows the comparison between the average grades achieved in research vs regular sections:

Table 4. Students final grades in research vs regular sections

\begin{tabular}{lllll}
\hline Sections/Grades & No. of Students & Average Group Grade & Highest Grade Obtained & Lowest Grade Obtained \\
\hline Research Group & 30 & 83 & 90 & 71 \\
Regular Group & 35 & 84 & 91 & 73 \\
\hline
\end{tabular}

As demonstrated in the Table 4 above, there were no significant differences in the grades achieved by students. It is assumed that since there were no differences in the course materials shared with the students and the type and number of exams placed during the semester, students' global performance in both sections remained analogous. We also ascertain that the use of software consumed some of the class time of the research section, thus, diverting their efforts from learning the concepts and theories to learn the software functions.

\subsection{Pre-Post Course Questionnaires}

Information was collected twice during the semester using similar questionnaires: One during the second week 
of the semester, and one, at the second last week of the semester. So, the time-gap between the pre-post questionnaire applications was around 10 weeks. The questionnaire was developed studying existing questionnaires in the literature (Western Carolina University, n/a) but substantially modified to suit this particular study. In the information analysis stage, considering the homogeneity of the study participants (gender, past experience and knowledge of negotiation, semester level, knowledge of negotiation, past experience), and observing the minuscule influence of these variables on the outcomes of the study, we decided to drop them from further analysis. And we decided to work further on the information collected through Negotiation self-confidence level assessment. To do that, in a scale of "1 to 5" students were asked to rate15-statements indicating the level of their self-confidence in any negotiation situation. Students rated each item in a scale of 1 to 5 where 1 = strongly disagree, $2=$ disagree, $3=$ neutral, $4=$ agree, $5=$ strongly agree. Pre-semester questionnaires were applied in a similar fashion. To simplify and shorten the information analysis, we decided to drop the categories of 1 and 2 (see Table 5) from further calculations, since these categories together represented only around $7 \%$ of the total responses obtained. Around $93 \%$ responses fell on categories 3, 4 and 5, and that is why we worked only with responses falling among these three categories. Items numbers 12, 13 and 14, were included in the questionnaire for the pre-semester survey with a purpose to allow students to evaluate their self-confidence levels, based on the expectations from the course prior the course work. For the post-semester survey purposes, all 15 items were equally applicable and important. Table 5 shows that around $30-40 \%$ of the students remained neutral about their confidence level in negotiation related abilities, and majority were satisfied with their negotiation abilities. However, very few showed strong belief in their negotiating abilities, even before taking the course (according to this survey).

Table 5. Regular group pre-semester self confidence level scores

\begin{tabular}{|c|c|c|c|c|c|c|c|c|}
\hline Items & $\begin{array}{l}1 \text { Strongly } \\
\text { Disagree }\end{array}$ & 2 Disagree & 3 Neutral & 4 Agree & $\begin{array}{l}5 \text { Strongly } \\
\text { Agree }\end{array}$ & $\begin{array}{l}\text { Total } \\
(3+4+5)\end{array}$ & $\begin{array}{l}\text { Total } \\
(4+5) \\
\end{array}$ & $\begin{array}{l}\% 4 \& 5 \text { of } \\
3+4+5\end{array}$ \\
\hline $\begin{array}{l}\text { I feel comfortable during the } \\
\text { negotiation }\end{array}$ & & & 12 & 13 & 5 & 30 & 18 & 60 \\
\hline $\begin{array}{l}\text { I am better prepared for any } \\
\text { negotiation event }\end{array}$ & & & 8 & 15 & 5 & 28 & 20 & 71 \\
\hline I feel less intimidated & & & 8 & 12 & 4 & 24 & 16 & 67 \\
\hline $\begin{array}{l}\text { I can interrelate cultural variables } \\
\text { and negotiation approach }\end{array}$ & & & 8 & 15 & 5 & 28 & 20 & 71 \\
\hline $\begin{array}{l}\text { I know very well about } \\
\text { negotiating styles }\end{array}$ & & & 13 & 7 & 0 & 20 & 7 & 35 \\
\hline $\begin{array}{l}\text { I can easily point out the effect of } \\
\text { cultural variables on } \\
\text { communication }\end{array}$ & & & 9 & 11 & 7 & 27 & 18 & 67 \\
\hline $\begin{array}{l}\text { I can easily identify common } \\
\text { ground in a conflict situation }\end{array}$ & & & 6 & 14 & 7 & 27 & 21 & 78 \\
\hline $\begin{array}{l}\text { I feel more confident during } \\
\text { negotiations }\end{array}$ & & & 12 & 10 & 3 & 25 & 13 & 52 \\
\hline $\begin{array}{l}\text { I can compare negotiating styles } \\
\text { in different settings }\end{array}$ & & & 10 & 10 & 3 & 23 & 13 & 57 \\
\hline $\begin{array}{l}\text { I can discriminate between } \\
\text { process and result focused } \\
\text { negotiations }\end{array}$ & & & 12 & 12 & 1 & 25 & 13 & 52 \\
\hline $\begin{array}{l}\text { I recognize strategies and tactics } \\
\text { used by others }\end{array}$ & & & 10 & 9 & 6 & 25 & 15 & 60 \\
\hline $\begin{array}{l}\text { I acquired more knowledge on } \\
\text { the negotiation tactics and } \\
\text { strategic options and am able to } \\
\text { identify them and even apply } \\
\text { them during the negotiation }\end{array}$ & & & 13 & 13 & 2 & 28 & 15 & 54 \\
\hline $\begin{array}{l}\text { I believe the exercises conducted } \\
\text { throughout the course actually } \\
\text { prepared me to negotiate better }\end{array}$ & & & 10 & 13 & 6 & 29 & 19 & 66 \\
\hline $\begin{array}{l}\text { I am satisfied that my ability to } \\
\text { negotiate has progressed } \\
\text { significantly over the course }\end{array}$ & & & 13 & 14 & 4 & 31 & 18 & 58 \\
\hline $\begin{array}{l}\text { I am satisfied with my } \\
\text { communication skills in } \\
\text { negotiation }\end{array}$ & & & 12 & 12 & 2 & 26 & 14 & 54 \\
\hline
\end{tabular}


Table 6 shows that around $30-40 \%$ of the students remained neutral about their confidence level in negotiation related abilities, and about $60 \%$ to $70 \%$ of students shown confident with their negotiation abilities.

Table 6. Regular group post-semester self confidence level scores

\begin{tabular}{|c|c|c|c|c|c|c|c|c|}
\hline Items & $\begin{array}{l}1 \text { Strongly } \\
\text { Disagree }\end{array}$ & 2 Disagree & 3 Neutral & 4 Agree & $\begin{array}{l}5 \text { Strongly } \\
\text { Disagree }\end{array}$ & $\begin{array}{l}\text { Total } \\
(3+4+5)\end{array}$ & $\begin{array}{l}\text { Total } \\
(4+5)\end{array}$ & $\begin{array}{l}\% 4 \& 5 \text { of } \\
3+4+5\end{array}$ \\
\hline $\begin{array}{l}\text { I feel comfortable during the } \\
\text { negotiation }\end{array}$ & & & 7 & 11 & 9 & 27 & 20 & 74 \\
\hline $\begin{array}{l}\text { I am better prepared for any } \\
\text { negotiation event }\end{array}$ & & & 5 & 11 & 11 & 27 & 22 & 81 \\
\hline I feel less intimidated & & & 3 & 12 & 11 & 26 & 23 & 88 \\
\hline $\begin{array}{l}\text { I can interrelate cultural } \\
\text { variables and negotiation } \\
\text { approach }\end{array}$ & & & 1 & 9 & 17 & 27 & 26 & 96 \\
\hline $\begin{array}{l}\text { I know very well about } \\
\text { negotiating styles }\end{array}$ & & & 4 & 11 & 10 & 25 & 21 & 84 \\
\hline $\begin{array}{l}\text { I can easily point out the effect } \\
\text { of cultural variables on } \\
\text { communication }\end{array}$ & & & 11 & 11 & 5 & 27 & 16 & 59 \\
\hline $\begin{array}{l}\text { I can easily identify common } \\
\text { ground in a conflict situation }\end{array}$ & & & 6 & 12 & 9 & 27 & 21 & 78 \\
\hline $\begin{array}{l}\text { I feel more confident during } \\
\text { negotiations }\end{array}$ & & & 7 & 10 & 10 & 27 & 20 & 74 \\
\hline $\begin{array}{l}\text { I can compare negotiating } \\
\text { styles in different settings }\end{array}$ & & & 8 & 10 & 9 & 27 & 19 & 70 \\
\hline $\begin{array}{l}\text { I can discriminate between } \\
\text { process and result focused } \\
\text { negotiations }\end{array}$ & & & 5 & 11 & 9 & 25 & 20 & 80 \\
\hline $\begin{array}{l}\text { I recognize strategies and } \\
\text { tactics used by others }\end{array}$ & & & 3 & 12 & 11 & 26 & 23 & 88 \\
\hline $\begin{array}{l}\text { I acquired more knowledge on } \\
\text { the negotiation tactics and } \\
\text { strategic options and am able to } \\
\text { identify them and even apply } \\
\text { them during the negotiation }\end{array}$ & & & 9 & 11 & 6 & 26 & 17 & 65 \\
\hline $\begin{array}{l}\text { I believe the exercises } \\
\text { conducted throughout the } \\
\text { course actually prepared me to } \\
\text { negotiate better }\end{array}$ & & & 2 & 16 & 9 & 27 & 25 & 93 \\
\hline $\begin{array}{l}\text { I am satisfied that my ability to } \\
\text { negotiate has progressed } \\
\text { significantly over the course }\end{array}$ & & & 1 & 14 & 12 & 27 & 26 & 96 \\
\hline $\begin{array}{l}\text { I am satisfied with my } \\
\text { communication skills in } \\
\text { negotiation }\end{array}$ & & & 2 & 11 & 14 & 27 & 25 & 93 \\
\hline
\end{tabular}

Table 7 shows the pre-post regular group scores shows that in 10 out of 12 items evaluated, students demonstrated positive change (see the observation column of Table 6) in their confidence levels when compared pre-semester and post-semester scores. 
Table 7. Regular group pre-post semester differences in self confidence level scores

\begin{tabular}{|c|c|c|c|c|}
\hline Items & $\begin{array}{l}\text { Regular Group } \% \\
4 \& 5 \text { of } 3+4+5 \\
\text { Presemester }\end{array}$ & $\begin{array}{l}\text { Regular Group } \% \\
4 \& 5 \text { of } 3+4+5 \text { Post } \\
\text { semester }\end{array}$ & $\begin{array}{l}\text { Differences between } \\
\text { Pre-Post Semester } \\
\text { Self-Confidence Level }\end{array}$ & $\begin{array}{l}\text { Observation (positive or negative } \\
\text { change, from Pre to Post Semester } \\
\text { Confidence Level) }\end{array}$ \\
\hline I feel comfortable during the negotiation & 60 & 74 & 14 & 14 points positive change \\
\hline I am better prepared for any negotiation event & 71 & 81 & 10 & 10 points positive change \\
\hline I feel less intimidated & 67 & 88 & 21 & 21 points positive change \\
\hline $\begin{array}{l}\text { I can interrelate cultural variables and } \\
\text { negotiation approach }\end{array}$ & 71 & 96 & 25 & 25 points positive change \\
\hline I know very well about negotiating styles & 35 & 84 & 49 & 49 points positive change \\
\hline $\begin{array}{l}\text { I can easily point out the effect of cultural } \\
\text { variables on communication }\end{array}$ & 67 & 59 & -8 & (-8 points) \\
\hline $\begin{array}{l}\text { I can easily identify common ground in a } \\
\text { conflict situation }\end{array}$ & 78 & 78 & 0 & 0 points change \\
\hline I feel more confident during negotiations & 52 & 74 & 22 & 22 points positive change \\
\hline $\begin{array}{l}\text { I can compare negotiating styles in different } \\
\text { settings }\end{array}$ & 57 & 70 & 13 & 13 points positive change \\
\hline $\begin{array}{l}\text { I can discriminate between process and result } \\
\text { focused negotiations }\end{array}$ & 52 & 80 & 28 & 28 points positive change \\
\hline $\begin{array}{l}\text { I recognize strategies and tactics used by } \\
\text { others }\end{array}$ & 60 & 88 & 28 & 28 points positive change \\
\hline $\begin{array}{l}\text { I acquired more knowledge on the negotiation } \\
\text { tactics and strategic options and am able to } \\
\text { identify them and even apply them during the } \\
\text { negotiation }\end{array}$ & 54 & 65 & 11 & 11 points positive change \\
\hline $\begin{array}{l}\text { I believe the exercises conducted throughout } \\
\text { the course actually prepared me to negotiate } \\
\text { better }\end{array}$ & 66 & 93 & 27 & 27 points positive change \\
\hline $\begin{array}{l}\text { I am satisfied that my ability to negotiate has } \\
\text { progressed significantly over the course }\end{array}$ & 58 & 96 & 38 & 38 points positive change \\
\hline $\begin{array}{l}\text { I am satisfied with my communication skills in } \\
\text { negotiation }\end{array}$ & 54 & 93 & 39 & 39 points positive change \\
\hline
\end{tabular}

Table 8 shows that around $20-30 \%$ of the research group students remained neutral about their confidence level in negotiation related abilities, and the rest of $70-80 \%$ were divided between agree and strongly agree ranges, showing satisfaction but not that strongly with their actual negotiation abilities, even before taking the course.

Table 8. Research group pre-semester self confidence level scores

\begin{tabular}{|c|c|c|c|c|c|c|c|}
\hline Items & $\begin{array}{l}1 \text { Strongly } 2 \text { Disagree } \\
\text { Disagree }\end{array}$ & 3 Neutral & 4 Agree & $\begin{array}{l}5 \text { Strongly } \\
\text { Agree }\end{array}$ & $\begin{array}{l}\text { Total } \\
(3+4+5) \\
\end{array}$ & $\begin{array}{l}\text { Total } \\
(4+5) \\
\end{array}$ & $\begin{array}{l}\% 4 \& 5 \text { of } \\
3+4+5\end{array}$ \\
\hline I feel comfortable during the negotiation & & 5 & 17 & 4 & 26 & 21 & 81 \\
\hline I am better prepared for any negotiation event & & 6 & 15 & 4 & 25 & 19 & 76 \\
\hline I feel less intimidated & & 6 & 11 & 8 & 25 & 19 & 76 \\
\hline $\begin{array}{l}\text { I can interrelate cultural variables and negotiation } \\
\text { approach }\end{array}$ & & 6 & 6 & 13 & 25 & 19 & 76 \\
\hline I know very well about negotiating styles & & 11 & 7 & 6 & 24 & 13 & 54 \\
\hline $\begin{array}{l}\text { I can easily point out the effect of cultural variables } \\
\text { on communication }\end{array}$ & & 4 & 13 & 11 & 28 & 24 & 86 \\
\hline $\begin{array}{l}\text { I can easily identify common ground in a conflict } \\
\text { situation }\end{array}$ & & 5 & 8 & 13 & 26 & 21 & 81 \\
\hline I feel more confident during negotiations & & 9 & 11 & 6 & 26 & 17 & 65 \\
\hline I can compare negotiating styles in different settings & & 7 & 11 & 6 & 24 & 17 & 71 \\
\hline $\begin{array}{l}\text { I can discriminate between process and result } \\
\text { focused negotiations }\end{array}$ & & 7 & 13 & 3 & 23 & 16 & 70 \\
\hline I recognize strategies and tactics used by others & & 4 & 12 & 8 & 24 & 20 & 83 \\
\hline $\begin{array}{l}\text { I acquired more knowledge on the negotiation } \\
\text { tactics and strategic options and am able to identify } \\
\text { them and even apply them during the negotiation }\end{array}$ & & 8 & 11 & 8 & 27 & 19 & 70 \\
\hline $\begin{array}{l}\text { I believe the exercises conducted throughout the } \\
\text { course actually prepared me to negotiate better }\end{array}$ & & 4 & 10 & 14 & 28 & 24 & 86 \\
\hline $\begin{array}{l}\text { I am satisfied that my ability to negotiate has } \\
\text { progressed significantly over the course }\end{array}$ & & 5 & 11 & 10 & 26 & 21 & 81 \\
\hline $\begin{array}{l}\text { I am satisfied with my communication skills in } \\
\text { negotiation }\end{array}$ & & 10 & 10 & 7 & 27 & 17 & 63 \\
\hline
\end{tabular}


Table 9 shows that around $10-20 \%$ of the students remained neutral about their confidence level in negotiation related abilities, and about $80 \%$ of students shown highly level of confidence in their negotiation abilities.

Table 9. Research group post-semester self confidence level scores

\begin{tabular}{|c|c|c|c|c|c|c|c|c|}
\hline Items & $\begin{array}{l}1 \text { Strongly } \\
\text { Disagree }\end{array}$ & 2 Disagree & 3 Neutral & 4 Agree & $\begin{array}{l}5 \text { Strongly } \\
\text { Agree }\end{array}$ & $\begin{array}{l}\text { Total } \\
(3+4+5)\end{array}$ & $\begin{array}{l}\text { Total } \\
(4+5)\end{array}$ & $\begin{array}{l}\% 4 \& 5 \text { of } \\
3+4+5\end{array}$ \\
\hline $\begin{array}{l}\text { I feel comfortable during the } \\
\text { negotiation }\end{array}$ & & & 5 & 13 & 8 & 26 & 21 & 81 \\
\hline $\begin{array}{l}\text { I am better prepared for any negotiation } \\
\text { event }\end{array}$ & & & 1 & 12 & 13 & 26 & 25 & 96 \\
\hline I feel less intimidated & & & 4 & 11 & 11 & 26 & 22 & 85 \\
\hline $\begin{array}{l}\text { I can interrelate cultural variables and } \\
\text { negotiation approach }\end{array}$ & & & 1 & 9 & 16 & 26 & 25 & 96 \\
\hline $\begin{array}{l}\text { I know very well about negotiating } \\
\text { styles }\end{array}$ & & & 4 & 14 & 8 & 26 & 22 & 85 \\
\hline $\begin{array}{l}\text { I can easily point out the effect of } \\
\text { cultural variables on communication }\end{array}$ & & & 1 & 16 & 7 & 24 & 23 & 96 \\
\hline $\begin{array}{l}\text { I can easily identify common ground in } \\
\text { a conflict situation }\end{array}$ & & & 1 & 10 & 14 & 25 & 24 & 96 \\
\hline $\begin{array}{l}\text { I feel more confident during } \\
\text { negotiations }\end{array}$ & & & 2 & 12 & 12 & 26 & 24 & 92 \\
\hline $\begin{array}{l}\text { I can compare negotiating styles in } \\
\text { different settings }\end{array}$ & & & 2 & 12 & 12 & 26 & 24 & 92 \\
\hline $\begin{array}{l}\text { I can discriminate between process and } \\
\text { result focused negotiations }\end{array}$ & & & 4 & 10 & 12 & 26 & 22 & 85 \\
\hline $\begin{array}{l}\text { I recognize strategies and tactics used } \\
\text { by others }\end{array}$ & & & 2 & 14 & 10 & 26 & 24 & 92 \\
\hline $\begin{array}{l}\text { I acquired more knowledge on the } \\
\text { negotiation tactics and strategic options } \\
\text { and am able to identify them and even } \\
\text { apply them during the negotiation }\end{array}$ & & & 5 & 16 & 4 & 25 & 20 & 80 \\
\hline $\begin{array}{l}\text { I believe the exercises conducted } \\
\text { throughout the course actually prepared } \\
\text { me to negotiate better }\end{array}$ & & & 4 & 12 & 10 & 26 & 22 & 85 \\
\hline $\begin{array}{l}\text { I am satisfied that my ability to } \\
\text { negotiate has progressed significantly } \\
\text { over the course }\end{array}$ & & & 3 & 12 & 11 & 26 & 23 & 88 \\
\hline $\begin{array}{l}\text { I am satisfied with my communication } \\
\text { skills in negotiation }\end{array}$ & & & 4 & 9 & 12 & 25 & 21 & 84 \\
\hline
\end{tabular}

Table 10 the pre-post research group scores show in 13 out of 15 items evaluated, students demonstrated positive change (see the observation column of Table 10) in their confidence levels when compared pre-semester and post-semester scores. 
Table 10. Research group pre-post semester differences in self confidence level scores

\begin{tabular}{|c|c|c|c|c|}
\hline Items & $\begin{array}{l}\text { Research } \% 4 \& 5 \\
\text { of } 3+4+5 \\
\text { Presemester }\end{array}$ & $\begin{array}{l}\text { Research } \% 4 \& 5 \text { of } \\
3+4+5 \\
\text { Postsemester }\end{array}$ & $\begin{array}{l}\text { Differences between } \\
\text { Pre-post Semester Self } \\
\text { Confidence Level }\end{array}$ & $\begin{array}{l}\text { Observations (Positive-Negative } \\
\text { Change from Pre to Post Semester } \\
\text { Confidence Level) }\end{array}$ \\
\hline $\begin{array}{l}\text { I feel comfortable during the } \\
\text { negotiation }\end{array}$ & 81 & 81 & 0 & 0 points change \\
\hline $\begin{array}{l}\text { I am better prepared for any } \\
\text { negotiation event }\end{array}$ & 76 & 96 & 20 & 20 points positive change \\
\hline I feel less intimidated & 76 & 85 & 9 & 9 points positive change \\
\hline $\begin{array}{l}\text { I can interrelate cultural variables and } \\
\text { negotiation approach }\end{array}$ & 76 & 96 & 20 & 20 points positive change \\
\hline $\begin{array}{l}\text { I know very well about negotiating } \\
\text { styles }\end{array}$ & 54 & 85 & 30 & 30 points positive change \\
\hline $\begin{array}{l}\text { I can easily point out the effect of } \\
\text { cultural variables on communication }\end{array}$ & 86 & 96 & 10 & 10 points positive change \\
\hline $\begin{array}{l}\text { I can easily identify common ground in } \\
\text { a conflict situation }\end{array}$ & 81 & 96 & 15 & 15 points positive change \\
\hline $\begin{array}{l}\text { I feel more confident during } \\
\text { negotiations }\end{array}$ & 65 & 92 & 27 & 27 points positive change \\
\hline $\begin{array}{l}\text { I can compare negotiating styles in } \\
\text { different settings }\end{array}$ & 71 & 92 & 21 & 21 pointspositive change \\
\hline $\begin{array}{l}\text { I can discriminate between process and } \\
\text { result focused negotiations }\end{array}$ & 70 & 85 & 15 & 15 points positive change \\
\hline $\begin{array}{l}\text { I recognize strategies and tactics used } \\
\text { by others }\end{array}$ & 83 & 92 & 9 & 9 points positive change \\
\hline $\begin{array}{l}\text { I acquired more knowledge on the } \\
\text { negotiation tactics and strategic } \\
\text { options and am able to identify them } \\
\text { and even apply them during the } \\
\text { negotiation }\end{array}$ & 70 & 80 & 10 & 10 points positive change \\
\hline $\begin{array}{l}\text { I believe the exercises conducted } \\
\text { throughout the course actually } \\
\text { prepared me to negotiate better }\end{array}$ & 86 & 85 & -1 & Negative \\
\hline $\begin{array}{l}\text { I am satisfied that my ability to } \\
\text { negotiate has progressed significantly } \\
\text { over the course }\end{array}$ & 81 & 88 & 8 & 8 points positive change \\
\hline $\begin{array}{l}\text { I am satisfied with my communication } \\
\text { skills in negotiation }\end{array}$ & 63 & 84 & 21 & 21 points positive change \\
\hline
\end{tabular}

When we look at the Tables 11 and 12, the research group maintains significant differences when compared with the regular group in the self-confidence level in any negotiation situation. In pre-semester evaluation, the research group scores high in almost all of the 15 items, and in the post-semester survey, they maintained upward difference except in three items where they have shown negative tendency. 
Table 11. Pre-semester regular vs research group self-confidence assessment score

\begin{tabular}{|c|c|c|c|c|}
\hline Items & $\begin{array}{l}\text { Regular Group \% } \\
4 \& 5 \text { of } 3+4+5 \\
\text { Presemester }\end{array}$ & $\begin{array}{l}\text { Research Group } \% \\
4 \& 5 \text { of } 3+4+5 \\
\text { Presemester }\end{array}$ & $\begin{array}{l}\text { Presemester: Differences } \\
\text { between Research and } \\
\text { Regular Groups }\end{array}$ & $\begin{array}{l}\text { Changes } \\
\text { in \%ages }\end{array}$ \\
\hline I feel comfortable during the negotiation & 60 & 81 & 21 & 35 \\
\hline I am better prepared for any negotiation event & 71 & 76 & 5 & 6 \\
\hline I feel less intimidated & 67 & 76 & 9 & 14 \\
\hline I can interrelate cultural variables and negotiation approach & 71 & 76 & 5 & 6 \\
\hline I know very well about negotiating styles & 35 & 54 & 19 & 55 \\
\hline $\begin{array}{l}\text { I can easily point out the effect of cultural variables on } \\
\text { communication }\end{array}$ & 67 & 86 & 19 & 29 \\
\hline I can easily identify common ground in a conflict situation & 78 & 81 & 3 & 4 \\
\hline I feel more confident during negotiations & 52 & 65 & 13 & 26 \\
\hline I can compare negotiating styles in different settings & 57 & 71 & 14 & 25 \\
\hline $\begin{array}{l}\text { I can discriminate between process and result focused } \\
\text { negotiations }\end{array}$ & 52 & 70 & 18 & 34 \\
\hline I recognize strategies and tactics used by others & 60 & 83 & 23 & 39 \\
\hline $\begin{array}{l}\text { I acquired more knowledge on the negotiation tactics and } \\
\text { strategic options and am able to identify them and even } \\
\text { apply them during the negotiation }\end{array}$ & 54 & 70 & 17 & 31 \\
\hline $\begin{array}{l}\text { I believe the exercises conducted throughout the course } \\
\text { actually prepared me to negotiate better }\end{array}$ & 66 & 86 & 20 & 31 \\
\hline $\begin{array}{l}\text { I am satisfied that my ability to negotiate has progressed } \\
\text { significantly over the course }\end{array}$ & 58 & 81 & 23 & 39 \\
\hline I am satisfied with my communication skills in negotiation & 54 & 63 & 9 & 17 \\
\hline
\end{tabular}

Table 12. Post-semester regular vs research groups self-confidence level scores

\begin{tabular}{|c|c|c|c|c|}
\hline Item & $\begin{array}{l}\text { Regular } \% \\
4 \& 5 \text { of } 3+4+5\end{array}$ & $\begin{array}{l}\text { Research } \% \\
4 \& 5 \text { of } 3+4+5\end{array}$ & $\begin{array}{l}\text { Differences between } \\
\text { Regular and Research } \\
\text { Groups }\end{array}$ & $\begin{array}{l}\text { Changes } \\
\text { in \%ages }\end{array}$ \\
\hline I feel comfortable during the negotiation & 74 & 81 & 7 & 9 \\
\hline I am better prepared for any negotiation event & 81 & 96 & 15 & 18 \\
\hline I feel less intimidated & 88 & 85 & -4 & -4 \\
\hline I can interrelate cultural variables and negotiation approach & 96 & 96 & 0 & 0 \\
\hline I know very well about negotiating styles & 84 & 85 & 1 & 1 \\
\hline $\begin{array}{l}\text { I can easily point out the effect of cultural variables on } \\
\text { communication }\end{array}$ & 59 & 96 & 37 & 62 \\
\hline I can easily identify common ground in a conflict situation & 78 & 96 & 18 & 23 \\
\hline I feel more confident during negotiations & 74 & 92 & 18 & 25 \\
\hline I can compare negotiating styles in different settings & 70 & 92 & 22 & 31 \\
\hline I can discriminate between process and result focused negotiations & 80 & 85 & 5 & 6 \\
\hline I recognize strategies and tactics used by others & 88 & 92 & 4 & 4 \\
\hline $\begin{array}{l}\text { I acquired more knowledge on the negotiation tactics and strategic } \\
\text { options and am able to identify them and even apply them during } \\
\text { the negotiation }\end{array}$ & 65 & 80 & 15 & 22 \\
\hline $\begin{array}{l}\text { I believe the exercises conducted throughout the course actually } \\
\text { prepared me to negotiate better }\end{array}$ & 93 & 85 & -8 & -9 \\
\hline $\begin{array}{l}\text { I am satisfied that my ability to negotiate has progressed } \\
\text { significantly over the course }\end{array}$ & 96 & 88 & -8 & -8 \\
\hline
\end{tabular}

\section{Conclusions, Implications and Recommendations}

The results are positive in terms of creativity, innovation and making the learning environment more challenging and appealing for the students. Although this pedagogical innovation study was designed to cover all those key elements which are relevant to the quality education such as continues improvement, incremental changes, and disruptive changes, nonetheless, the study outcomes are helpful to revolutionize somehow the existing educational paradigms in the field of negotiation education. Though the information analysis does not indicate radical differences between the regular and research groups, however, students were found taking extra interest and putting extra efforts in learning the software and use it for solving a business problem or negotiating a 
business transaction. The outcomes of the observation's notes, students end-semester comments about the course, and the marginal changes in the self-confidence level of students in their negotiation abilities reflect that modernizing the pedagogical approaches in the institutions of higher education should be a priority for the university management.

We foresee several implications as a consequence of such studies for the academic leadership, and of which some are shortlisted below:

- University management will have to build its education model with ICT being at its core.

- Academic leadership will have to provide enough resources to incorporate ICT related support systems into the existing education model (especially, pedagogical approaches).

- Training the faculty and students alike to enable them to work with technology.

- Developing ability and willingness to change from an established education system to a novel and dynamic teaching and learning environment. It is time and money demanding.

Based on these findings we recommend the university management to:

- Revolutionize its existing education model in different dimensions by incorporating the emerging ICT platforms.

- Encourage the use of professional technologies or educational technologies which not only help students learning effectively, but also prepare them to be able to participate actively and productively in the emerging digitalized professional-social environment and thus leading them to contribute to the progress of society, economy and business.

- Use software to teach courses since it can enhance the interest and motivation levels of students and at the same time will make it easier for the faculty to keep engaged the students.

\section{Limitations in the Research and Future Studies}

A few limitations are associated with the study process and outcome. One, since the study involved the use of technology or software, the technical complexities and technology failures were the main hindrances and influential factors in complicating the process and jeopardizing the desired outcome. Second, the degree and level of support needed from the students participating in the study was not available. Keeping them motivated throughout the project, encouraging them to learn by doing, and expecting them learn theories before working with the software were not always within the control of the faculty. Third, there are other factors such as the learning capabilities and previous experiences of individual students, which might have impacted their learning experience and performance on the course. And not necessarily the use of a particular software to support teaching and learning was an influential factor in their learning. Future studies can address these factors combined with experimenting such pedagogical strategies in several sections and involve more faculty.

\section{Reference}

Bruce, B. C., \& Levin, J. A. (1997). Educational technology: Media for inquiry, communication, construction, and expression. Journal of Educational Computing Research, 17(1), 79-102. https://doi.org/10.2190/7HPQ-4F3X-8M8Y-TVCA

Buabeng-Andoh, C. (2012). Factors Influencing Teachers' Adoption and Integration of Information and Communication Technology into Teaching: A Review of the Literature. International Journal of Education and Development Using Information and Communication Technology, 8, 136-155.

Downing, J., \& Garmon, C. (2001). Teaching students in the basic course how to use presentation software. Communication Education, 50, 218-229. https://doi.org/10.1080/03634520109379249

Driver, M. (2002). Investigating the benefits of Web-centric instruction for student learning: An exploratory study for an MBA course. Journal of Education for Business, 77(4), 236-246. https://doi.org/10.1080/08832320209599078

Gentry, C. G. (1995). Educational technology: A question of meaning. In G. Anglin (Ed.), Instructional technology: Past, present, and future. Englewood, CO: Libraries Unlimited.

Mahwah (Ed.). Instructional-design theories and models. New Jersey/London: Lawrence Erlbaum.

McCannon, M., \& Crews, B. T. (2000). Assessing the technology training needs of elementary school teachers. Journal of Technology and Teacher Education, 8(2), 111-121.

Mehar, H. (2015). Software Based Approach for Teaching in Electrical Engineering Classroom Courses: A Case 
Study. TELKOMNIKA. Indonesian Journal of Electrical Engineering, 15(2), 361-367.

OECD. (2010). Are the new millennium learners making the grade? Technology use and educational performance in PISA: Centre for Educational Research and Innovation, OECD.

Roblyer, M. D. (2006). Integrating educational technology into teaching (Vol. 2). Pearson/Merrill Prentice Hall.

See, J. (1994). Technology and Outcome-Based Education: Connections in Concept and Practice. The Computing Teacher, 17(3), 30-31.

Shaw, J. B., Fisher, C. D., \& Southey, G. N. (1999). Evaluating organizational behavior teaching innovations: More rigorous designs, more relevant criteria, and an example. Journal of Management Education, 23(5), 509-536. https://doi.org/10.1177/105256299902300505

Snelbecker, G. E. (1999). Current progress, historical perspective, and some tasks for the future of instructional theory. In C. M. Reigeluth (Ed.), Instructional-design theories and models (Volume 2, A new paradigm of instructional theory, pp. 653-674). Mahwah, NJ: Lawrence Erlbaum Associates.

Tondeur, J., van Keer, H., van Braak, J., \& Valcke, M. (2008). ICT integration in the classroom: challenging the potential of a school policy. Computers \& Education, 51(1), 212-223. https://doi.org/10.1016/j.compedu.2007.05.003

Webber, C. (2003). Introduction New Technologies and Educative Leadership. Journal of Educational Administration, 41(2), 119-123. https://doi.org/10.1108/09578230310477013

Western Carolina University. (n/a). The Coulter Faculty Commons (CFC) for Excellence in Teaching \& Learning, located in the Hunter Library. Retrieved from https://www.wcu.edu/learn/faculty/coulter-faculty-commons/

\section{Copyrights}

Copyright for this article is retained by the author, with first publication rights granted to the journal.

This is an open-access article distributed under the terms and conditions of the Creative Commons Attribution license (http://creativecommons.org/licenses/by/4.0/). 